\title{
Analysis of the Influence of Competitive Advantages and Motivations on the Performance of SMEs Assisted by Bank Sumatera Utara Kampung Baru Medan Branch
}

\author{
Kiki Farida Ferine
}

Universitas Pembangunan Panca Budi, Medan, Indonesia, 20122

\begin{abstract}
This research aims to find out and analyze the performance of SMEs Assisted by Bank Sumatera Utara Kampung Baru Medan Branch through Competitive Advantage and Motivation. The data analysis method used in this study uses Multiple Regression Analysis by conducting data quality tests, classic assumption tests, hypothesis tests and determination coefficients using the Statistical Package for Social Science (SPSS) program. The population in this study was all SMEs assisted by Bank Sumatera Utara Kampung Baru Medan Branch which amounted to 53 respondents. The entire population is used as a sample. The results of this study prove that partially Competitive Advantage has a positive and significant effect on the Performance of SMEs Assisted by Bank Sumatera Utara Kampung Baru Medan Branch and is dominant in influencing the Performance of SMEs Assisted by Bank Sumatera Utara Kampung Baru Medan Branch. Simultaneously Competitive Advantages And Motivation To The Performance of SMEs assisted by Bank Sumatera Utara Kampung Baru Medan Branch.
\end{abstract}

Keywords: Competitive Advantages, Motivation and Performance

\section{INTRODUCTION}

Small and Medium Enterprises (SMEs) generally have advantages in fields that utilize natural resources and laborintensive, such as agricultural food crops, plantations, farms, fisheries, trade and restaurants. The atmosphere or conditions at work should be designed as comfortable as possible for employees because this will have an effect on its performance. All organizations will have different working climates, which will be adapted to the strategy in human resource management of the company, workers / employees as human resources require open communication within the limits of their respective authorities and responsibilities.

Smooth communication to obtain information that is considered important by workers /employees and delivered on time, can cause complacency and create positive work motivation. human resource management is very concerned about the work process of employee performance in accordance with the workload in the organization by creating a harmonious environment, where the relationship of the company's leadership with employee performance and the relationship between divisions /parts in an organization will have a healthy and comfortable impact among fellow employees, because employees are one of the important capital (Human Capital) for the company. A good manager is a person who has strong needs for Power, a manager must manage the performance of others. An entrepreneur should monitor both success and failure in making sales, take responsibility for calling potential clients, take calculated risks, have to make decisions about prospects to follow up on, and find innovative ways to persuade people to buy their products or services. In 
addition, micro and small businesses are expected to develop into medium and large scale businesses. Developing SME performance is not easy. Barbara (2000) said that management problems in marketing, finance, technology greatly affect the development of SME performance. This weakness is evidenced by the research of BI Medan Branch in collaboration with the University of North Sumatra (USU) in October 2008, only $22.5 \%$ of SMEs have financial statements and $87.8 \%$ of SMEs prepare financial statements inappropriately.

This is due to low education and lack of understanding of Financial Accounting Standards and the absence of regulations that require the preparation of financial statements for SMEs and SMEs still concurrently tasked in carrying out their business in the field of marketing, operations, managing human resources and finance and transactions are also still simple. Climate in the organization affects 4 (four) principles such as a. Manager / leader. B. Employee behavior. c. Working group behavior and $\mathrm{d}$. Working group behavior. Had the government set rules on awarding wages and prices that could limit increased profits, employees might have become unhappy and could be out to get jobs at other companies. On the other hand, an economic boom can drive sales and allow everyone to get jobs and increase profits, resulting in a more positive climate. Bank Sumatera Utara is a regional bank that participates in the development of micro and small businesses in the North Sumatra region, through the disbursement of micro and small business loans, which in its realization found many obstacles stemming from the construction business itself that caused the purpose of lending is not felt to the maximum by the micro enterprise.

Bank Sumatera Utara conducts coaching activities towards micro businesses, considering that the loyalty of micro-entrepreneurs to The Bank of North Sumatra is very high, so that long-term relationships can be established with the
Bank through promotions conducted by word of mouth delivered in the family environment of micro-entrepreneurs, inviting families to become customers of Bank Sumatera Utara. In addition, many obstacles faced by North Sumatra Bank in conducting micro business development activities, among others, the difficulty of implementing a coaching program considering the low level of education of micro entrepreneurs and even many illiterate, in addition to other obstacles derived from the Bank of North Sumatra itself, because The Bank of North Sumatra in micro business development activities represent to the Account Officer (AO) of The Bank of North Sumatra to form a business group, and not all AOs have adequate capabilities to conduct micro business development activities. Based on the background described above researchers are interested to conduct research with the title of influence of climate work and motivation on the performance of SMEs Assisted by Bank Sumatera Utara Kampung Baru Medan Branch.

\section{LITERATURE REVIEW Competitive Advantages}

Competitive advantage basically grows from the value or benefit created by the company for its buyers which is more than the cost that must be spent to create it. It is this value or benefit that the buyer is prepared to pay, and the superior value comes from a lower bid price than the competitor's price for an equivalent benefit or a unique benefit offer that exceeds the offered price. Competitive advantage is a collection of strategies to determine the superiority of a company from competition among other companies. According to Muhammad stated that the company seeks to produce and market goods and services with a competitive strategy that makes the superiority of other companies.

Day and Wensley (1988) stated that there are two footholds in achieving competitive advantage, namely resource excellence and positional excellence. 
Whereas according to Droge et. al (1995) the competitive advantage that the company has will ultimately affect the company's market performance as measured through customer growth. Basically the development of a competing strategy is to develop a general formula of how businesses will compete, what exactly is the goal, and what policies will be needed to achieve those goals. Competing strategies are a combination of the ultimate goal that companies fight for with tools (policies) where companies try to get there (Prakosa, 2005). The strategy must be designed to realize a continuous competitive advantage, so that the company can dominate the old market as well as the new market.

\section{Motivation}

According to Robbins and Judge (2008) defines motivation as a process that explains the intensity, direction and perseverance of efforts to achieve a goal. Vroom (1964) in Luthans (2006) says the strength of motivation is valence and hope. The theory of hope argues that work motivation is determined by individual beliefs related to, business-performance relationships (expectancy $=$ expectations), work-outcome relationships (instrumental $=$ intermediaries), and perceptions of the importance of various work outcomes $($ valence $=$ valence $)$.

\section{Motivational Principles}

There are several principles in motivating the work of employees according to Mangkunegara (2009:61) including

\section{a. Principle of participation}

In an effort to motivate work, employees need to be given the opportunity to participate in determining the goals to be achieved by leaders of communication principles. Leaders communicate everything related to the efforts of achievement of tasks, with clear information, employees will be more easily motivated work b. The principle of recognizing the contribution of subordinates

The leader acknowledges that the (officer) has a part in the effort to achieve the objectives. With this recognition, employees will be more easily motivated to work.

c. Principle of delegation of authority

Leaders who give authority or authority to subordinate employees to at any time can make decisions on the work they do, will make the employee concerned become motivated to achieve the goals expected by the leader.

d. The principle of paying attention

Leaders pay attention to what employees want

\section{Performance}

Understanding performance is a result of work produced by an employee is interpreted to achieve the expected goals. According to Tika (2006) performance as a result of the function of work /activities of a person or group in an organization that is influenced by various factors to achieve organizational goals within a certain period of time. According to Rivai (2006) the definition of performance is the willingness of a person or group of people to do something and perfect it according to the responsibility with the results as expected. According to Alex (2001: 109), there are various factors of employee performance, including:

1) The amount and composition of compensation awarded

2) Proper work placement

3) Training and promotion

4) Security in the future (with severance and so on)

5) Relationships with co-workers

6) Relationships with leaders

From some of the above factors, it can be concluded that there are many factors that affect the performance of employees. Among them are internal factors, among others: intellectual ability, work discipline, job satisfaction and employee motivation. 
External factors include: leadership style, work environment, compensation and management system available in the company. These factors should be considered by the leadership so that employee performance can be optimal.

\section{Hypothesis}

Based on the theoretical explanation above and the frame of mind, the hypotheses that can be submitted are as below:

$\mathrm{H} 1$ : There is a positive influence of excellence compete against the performance of SMEs assisted by Bank Sumatera Utara Kampung Baru Medan Branch

$\mathrm{H} 2$ : There is a positive influence of motivation on the performance of SMEs assisted by Bank Sumatera Utara Kampung Baru Medan Branch

H3: There is a positive influence of competitive advantage and motivation on the performance of SMEs assisted by Bank Sumatera Utara Kampung Baru Medan Branch

\section{METHODOLOGY}

\section{Types of Research}

This type of research is associative, which aims to see if there is an influence of competitive advantage and motivation on the performance of SMEs assisted by Bank Sumatera Utara Kampung Baru Branch. According to Sugiyono (2003), that the nature of associative research basically wants to test the truth of a hypothesis implemented through data collection in the field.

\section{Research Location}

This research was conducted at Bank Sumatera Utara Branch Kampung Baru Medan Branch Jalan Brigjend Katamso no.717 B Medan.

\section{Population and Samples}

The population in this study was SMEs assisted by Bank Sumatera Utara Kampung Baru Medan Branch with a total of 111 SMEs (Bank Sumatera Utara, 2018). The sampling method in this study was based on the Slovin formula.
The sample was taken using the Slovin formula (Ginting 2008: 132) as follows:

$n=\frac{N}{1+N e^{2}}$

Description

$\mathrm{n}$ : Sample

$\mathrm{N}$ : Total Population

e : standard error

Then:

$$
n=\frac{111}{1+111 .(0,1)^{2}}=52,6
$$

In this study, the number of samples was rounded up to 53 SMEs assisted by Bank Sumatera Utara Kampung Baru Medan Branch.

\section{Data Collection Techniques}

Data collection techniques in this study were conducted through questionnaires, observations and documentation studies, as follows:

a. Questionnaire list given to SMEs assisted by Bank Sumatera Utara Kampung Baru Medan Branch.

b. Direct observation of decision makers and their physical environment and or direct observation of an ongoing activity.

c. Documentation study is conducted by collecting and studying supporting data in the form of organizational structure, work programs, and some other data obtained directly at Bank Sumatera Utara Kampung Baru Medan Branch.

\section{Variable Operational Definitions} follows:

Variables in this study are as

1. Competitive advantage (X1) is a company trying to produce and market goods and services with a competitive strategy that makes the advantage of other companies.

2. Motivation (X2) is a process that explains the intensity, direction and perseverance of efforts to achieve a goal. 
3. Performance $(\mathrm{Y})$ is the result of work produced by an employee is interpreted to achieve the expected goals.

\section{Data Analysis Techniques \\ Validity and Reliability Test}

\section{a. Validity Test}

According to Ghozali (2005), validity test is used to measure the validity or validity of the questionnaire. A questionnaire is said to be valid if the question on the questionnaire is able to reveal something that will be measured by the questionnaire". According to Sugiyono (2005), "If the validity value of each question is greater than the correlation coefficient value (r) of 0.30 then thebutir question is considered valid".

\section{b. Reliability Test}

A questionnaire is said to be reliable or reliable if a person's answer to a statement is consistent or stable over time. Testing is done by trying the instrument only once, then the data obtained is analyzed with a specific technique, in this case the technique used is Cronbach's alpha technique (a). A variable is said to be reliable if it provides a Cronbach's Alpha value of $>0.60$ (Ghozali, 2005).

\section{Statistical Test}

\section{a. t Test (Partial Test)}

The $t$ test aims to see the influence of competitive advantage and partial motivation on the performance of SMEs assisted by Bank Sumatera Utara Kampung Baru Medan Branch.

Partial hypothesis testing criteria are as follows:

Ho:b1,2=0, Meaning that competitive advantage and partial motivation have no effect on the performance of SMEs assisted by Bank Sumatera Utara Kampung Baru Medan Branch

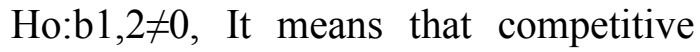
advantage and motivation partially affect the performance of SMEs assisted by Bank Sumatera Utara Kampung Baru Medan Branch

b. F Test (Simultaneous Test)

Test $\mathrm{F}$ is used to determine the influence of competitive advantage and motivation simultaneously on the performance of SMEs assisted by Bank Sumatera Utara Kampung Baru Medan Branch with a confidence level of $95 \%$ ( $=5 \%)$. The hypothetical model used in this $\mathrm{F}$ test is: Ho:b1, b2 = 0 Means that competitive advantage and motivation in aerempa has no effect on the performance of SMEs binaanBank North Sumatra Branch Kampung Baru Medan Ho:b1, b2 $\neq 0$ Means competitive advantage and motivation simultaneously affect the performance of SMEs assisted by Bank Sumatera Utara Kampung Baru Medan Branch

The decision-making criteria are:

Ho is accepted if Fcalculate < Ftabel, at $=5 \% \mathrm{Ho}$ is rejected ( $\mathrm{Ha}$ accepted) if Fcalculate $>$ Ftabel, at $=5 \%$

\section{Determination Coefficient Test (R2)}

The determination coefficient test (R2) is used to determine the percentage of influence of a free variable simultaneously on a bound variable. In other words, this coefficient shows how much the percentage of free variable variations used in the model is able to explain the bound variable variation. The value of $\mathrm{R} 2$ is between zero and one. A small R2 value means the ability of free variables to describe bound variables is very limited. A value that is close to one means that free variables provide almost all the information needed to predict bound variables.

\section{Classic Assumptions}

Classic assumption tests need to be conducted to ensure that multiple linear regression statistical test kits can be used or not.

\section{Normality Test}

Normality tests are conducted to see if in the regression model free variables and 
bound variables have normally distributed data or not. According to Sugiyono (2005) that, "The best model is if the data is distributed normally or close to normal. If the data spreads around the diagonal line and follows the diagonal direction, then the regression model meets the assumption of normality. Conversely, if the data spreads away from the diagonal line and or does not follow the diagonal line direction, then the regression model does not meet the assumption of normality."

\section{Multicollinearity Test}

Multicollinearity tests are conducted to determine whether or not a free variable has similarities to other free variables in a model that can lead to a very strong correlation between those free variables. To detect the presence of multicollinearity in a model can be seen from the value of Variance Inflation Factor (VIF). If the VIF value is not more than five then the regression model can be said to be free of multicollinearity. Conversely, if the VIF value is greater than five then the regression model is thought to have multicollinearity issues.

\section{Heteroskedasticity Test}

The heteroskedasticity test aims to determine whether there is a difference in residual variation of an observation period to another observation period, or an overview of the relationship between the predicted value and the standardized delete residual value. Heteroskedastisitas can be tested using the graph method, namely by looking at the absence of certain patterns drawn on the chart. If the pattern of formed dots forms a regular pattern (wavy, widened, then narrowed), then there has been heteroskedastisitas in the regression model. Conversely, if there is no clear pattern in which the dots spread above and below zero on the $\mathrm{Y}$ axis, then there is no heteroskedastisitas in the regression model (Ghozali, 2005)

\section{RESULTS AND DISCUSSION Validity and Reliability Test}

The validity test in this study was conducted by calculating Pearson product moment correlation (r) or by looking at the corrected item-total correlation value in SPSS Program version 22.0. It is said to be valid if the value of $r$ counts is over $r$ table. If the $r$ count is below the table $r$, then the question item must be discarded and no longer included in subsequent tests. Validity test results for both competitive advantage variables, motivation, and performance that are already valid and can be used further tests can be seen as follows:

\begin{tabular}{|c|c|c|}
\hline & $\begin{array}{l}\text { Scale Mean if Item } \\
\text { Deleted }\end{array}$ & $\begin{array}{ll}\text { Corrected } & \text { Item-Total } \\
\text { Correlation } & \\
\end{array}$ \\
\hline KB1 & 24,3962 & ,748 \\
\hline KB 2 & 24,1887 & ,757 \\
\hline KB 3 & 24,3396 & ,573 \\
\hline KB 4 & 24,2642 & ,481 \\
\hline KB 5 & 24,3396 & 639 \\
\hline KB 6 & 23,7358 & ,645 \\
\hline KB 7 & 23,9811 & ,339 \\
\hline
\end{tabular}

Validity tests conducted for all competing advantage variable statement items show that the correlation coefficient value of $\mathrm{KB} 1-\mathrm{KB} 7$ presented in the rhitung (corrected item- total correlation) column above is 0.3 so that it can be said that the competing advantage variable statement item is valid and can be used for subsequent tests.

Table 2: MotivationAl Validity Test

\begin{tabular}{|l|l|l|}
\hline & $\begin{array}{c}\text { Scale Mean If Item } \\
\text { Deleted }\end{array}$ & $\begin{array}{l}\text { Corrected } \\
\text { Correlation }\end{array}$ \\
\hline M1 & 15.5849 & .734 \\
\hline M2 & 15.4151 & .784 \\
\hline M3 & 15.5660 & .600 \\
\hline M4 & 15.4906 & .522 \\
\hline M5 & 15.5283 & .591 \\
\hline \multicolumn{3}{|c|}{ Source: Data processed (2020) }
\end{tabular}

Validity tests conducted for all motivation variable statement items show that the correlation coefficient value M 1 M5 presented in the rhitung column (corrected item- total correlation) above is 0.3 so it can be said that the motivation variable statement item is valid and can be used for subsequent tests. 
Kiki Farida Ferine. Analysis of the influence of competitive advantages and motivations on the performance of SMEs assisted by Bank Sumatera Utara Kampung Baru Medan Branch.

\begin{tabular}{|c|c|c|}
\hline & $\begin{array}{l}\text { Scale Mean if Item } \\
\text { Deleted }\end{array}$ & $\begin{array}{ll}\text { Corrected } \\
\text { Correlation }\end{array}$ \\
\hline K1 & 20.1132 & .743 \\
\hline $\mathrm{K} 2$ & 19.9434 & .781 \\
\hline K3 & 20.0943 & .609 \\
\hline K4 & 20.0189 & .504 \\
\hline K5 & 20.0566 & .615 \\
\hline K6 & 19.3962 & .447 \\
\hline
\end{tabular}

Validity tests performed for all performance variable statement items show that the $\mathrm{K} 1$ - K6 correlation coefficient value presented in the rhitung (corrected item- total correlation) column is above 0.3 so that it can be said that the Performance variable statement item is valid and can be used for subsequent tests.

Table 4 : Reliability Test

\begin{tabular}{|l|l|l|l|}
\hline No & Variable & $\begin{array}{l}\text { Alpha } \\
\text { Value }\end{array}$ & Conclusion \\
\hline 1 & Competitive Advantages $\left(\mathrm{X}_{1}\right)$ & .839 & Reliabel \\
\hline 2 & Motivation $\left(\mathrm{X}_{2}\right)$ & .840 & Reliabel \\
\hline 3 & Performance $(\mathrm{Y})$ & .836 & Reliabel \\
\hline \multicolumn{3}{|c|}{ Source: Data processed (2020) } \\
\hline
\end{tabular}

Alpha value of each variable magnitude above 0.6 so that the instrument used in this study is reliable (reliable) so that it can be used for further tests.

\section{Classic Assumption Test}

The normality test aims to test whether in the regression model, disruptive or residual variables have a normal distribution (Ghozali, 2005). As it is known that the $\mathrm{F}$ test and $\mathrm{t}$ test assume that the residual value follows the normal distribution.. This test can be done with a histogram approach. Normality test results using histogram approach.

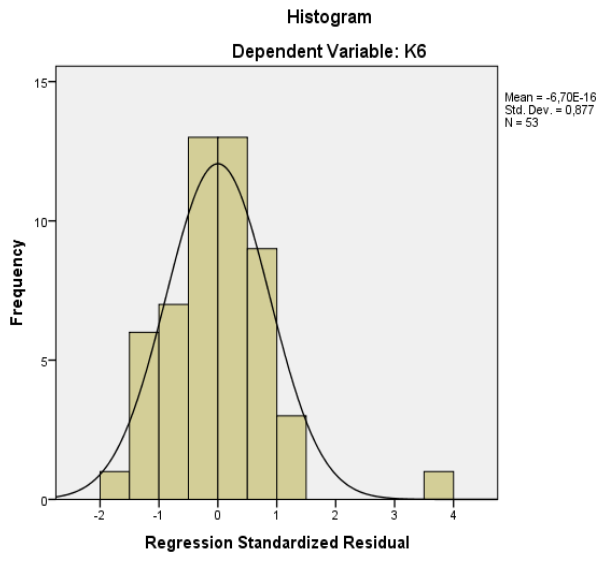

Figure 2 : Histogram

Table 5 : Multicolerity Test
\begin{tabular}{|l|l|l|l|}
\hline No & Variable & Tolerance & VIF \\
\hline 1 & Competitive Advantages $\left(\mathrm{X}_{1}\right)$ &, 709 & 1,410 \\
\hline 2 & Motivation $\left(\mathrm{X}_{2}\right)$ &, 435 & 2,297 \\
\hline \multicolumn{3}{|c|}{ Source: Data processed $(2020)$} \\
\end{tabular}

Based on the table can be seen that the tolerance value is still below the number 1 or above 0.1 this indicates the correlation coefesien between independent variables does not occur multicolinearity, similarly if seen from the value variance Inflaction Factor (VIF) is also still below the value of 5 , then it means that there is no multicolinearity in independent variables

\section{Heteroskedastisitas Test}

This test is conducted in a regression model whether in a regression model there is a variance of residual inequality from one observation to another. If the residual variance from one observation to another remains, then it is called homokedasitas. On the contrary if variance is different then it is called heteroskedastisitas. As for a good regression model is a regression model that does not occur heteroskedastisitas. From the graph presented in the image below, it appears that the dots spread randomly and do not form a specific pattern and are clear.

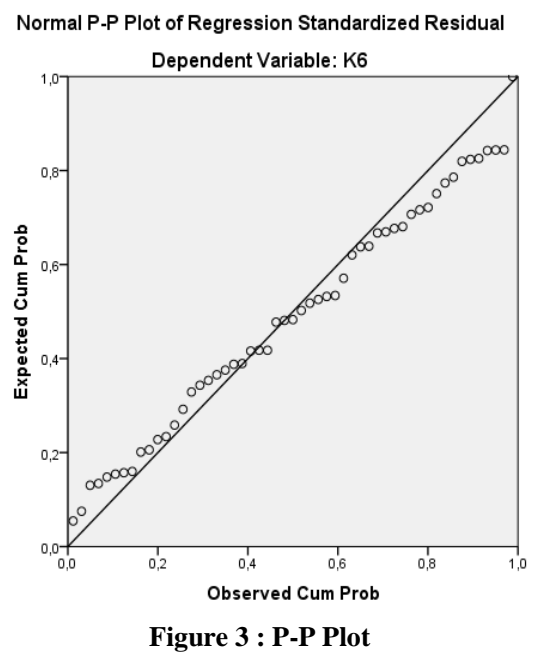

\section{Regression Estimation Results (Linear Model) Coefficient of Determination}

Researchers using SPSS program, present the results of data processing for 
Kiki Farida Ferine. Analysis of the influence of competitive advantages and motivations on the performance of SMEs assisted by Bank Sumatera Utara Kampung Baru Medan Branch.

coefficient of determination in the table below:

Table 6 : Coefficient of Determination

\begin{tabular}{|c|c|c|c|}
\hline Model & $\mathbf{R}$ & R square & Adjusted R square \\
\hline 1 &, $881^{\mathrm{a}}$ &, 777 & 710 \\
\hline
\end{tabular}

The $\mathrm{R}$ Square value obtained amounted to 0.777 which means that $77.7 \%$ of the performance of SMEs assisted by Bank Sumatera Utara Kampung Baru Medan branch can be explained by competitive advantage factors and motivation while the remaining $22.3 \%$ is explained by other factors such as competence, organizational commitment, compensation and others that are not researched in this study so as to further affect the performance of SMEs Assisted by Bank Sumatera Utara Kampung Baru Medan Branch.

\section{Simultaneous or Simultaneous Test (Test F)}

Simultaneous or simultaneous test or F test aims to test the first hypothesis of knowing the influence or not significantly independent variables together (simultaneously) on dependent variables. Below are presented the results of Test $F$ using SPSS.22

\begin{tabular}{|c|c|c|c|c|}
\hline Model & Sum of Squares & Mean Sauare & $\mathbf{F}$ & Sig. \\
\hline Reg & 11,813 & ,984 & 11,600 &, $000^{\mathrm{b}}$ \\
\hline Res & 3,395 & ,085 & & \\
\hline Total & 15,208 & & & \\
\hline $\begin{array}{l}\text { Depend } \\
\text { Predictors } \\
\text { KB6, KB1, }\end{array}$ & $\begin{array}{l}\text { Variable: } \mathrm{K} 6 \\
\text { Constant), M5, } \\
B 2\end{array}$ & $K B 7, K B 3$, & $M 1,1$ & $M 2$, \\
\hline
\end{tabular}

Based on the data in table 7 it can be seen that Fhitung $=11.600$ with a significance level of $0.000 \mathrm{~b}$. When compared to Ftabel at a confidence level of $5 \%(\mathrm{p}=0.05)$ which is only 3.18 , the value of Fhitung is greater than the value of Ftabel \{Fhitung $(11,600)<$ Ftabel $(3.18$ so it can be said that Competitive Advantage and Motivation simultaneously is a significant explanation variable to the performance of SMEs Assisted by Bank Sumatera Utara Kampung Baru Medan Branch.

\section{Partial Test (t Test)}

Partial test or $t$ test has the purpose to test the second hypothesis that is to know the influence or not significantly independent variables individually (partial) to dependent variables. Below are presented t Test results using SPSS.22

Table 8 : t Test
\begin{tabular}{|c|l|l|l|}
\hline \multicolumn{2}{|c|}{ Model } & t & Sig. \\
\hline \multirow{3}{*}{1} & (Constant) & 5,312 &, 000 \\
& Competitive Advantage & 8,200 &, 000 \\
& Motivation &, 880 &, 384 \\
\hline
\end{tabular}
a. Dependent Va a. Dependent variable: Performance
Source: Data processed (2020)

To determine ho or $\mathrm{H} 1$ rejected or accepted then thitung value compares with the value of ttabel at the level of significance $5 \%(\mathrm{p}=0.05)$, where the value of ttabel at the level of significance 5\% (p = 0.05 ) is 1,960 then can be concluded as follows:

1. Variable Competitive Advantage Variable Competitive Advantage has a significant effect on the Performance of SMEs Assisted by Bank Sumatera Utara Kampung Baru Medan Branch. This can be seen in the thitung value which reaches 8,200 above the 1,960ttabel value

2. MotivationAl Variables

Variable Motivation has no significant effect on the performance of SMEs assisted by Bank Sumatera Utara Kampung Baru Medan Branch. This can be seen in the thitung value which reaches 0.880 below the value of 1,960

\section{Regression Model (Linear Model)}

Based on the results of the estimation or regression, the equation of regression can be formulated as follows: $\mathrm{Y}=5,312+8,200 \mathrm{X}_{1}+0,880 \mathrm{X}_{2}$

\section{Competitive Advantage Factor}

The regression coefficient shows a positive direction giving meaning of a direct (positive) relationship between Competitive Advantage and performance. If competitive advantage undergoes changes or improvements then performance will also increase and vice versa if competitive 
Kiki Farida Ferine. Analysis of the influence of competitive advantages and motivations on the performance of SMEs assisted by Bank Sumatera Utara Kampung Baru Medan Branch.

advantage decreases then performance also decreases. The regression coefficient of 8,200 means that if there is a change or increase in competitive advantage of 1 (one) unit then the performance will increase by 8,200 units.

\section{Motivation Factors}

The regression coefficient shows a positive direction giving meaning of a direct (positive) relationship between motivation and performance. If motivation changes or improves then performance will also increase and vice versa if motivation decreases then performance also decreases. The regression coefficient of 0.880 means that if there is a change or increase in Motivation of 1 (one) unit then the performance will increase by 0.880 units.

\section{CONCLUSION}

Based on the tests that have been done, it can be concluded as follows:

1. Partial competitive advantage has a positive and significant effect on the performance of SMEs Assisted by Bank Sumatera Utara Kampung Baru Medan Branch.

2. Partial motivation has no significant effect on the performance of SMEs assisted by Bank Sumatera Utara Kampung Baru Medan Branch.

3. Simultaneously Competitive Advantage and Motivation have a positive and significant effect on the performance of SMEs Assisted by Bank Sumatera Utara Kampung Baru Medan Branch.

4. The R Square value obtained is 0.777 which means that $77.7 \%$ of the performance of SMEs assisted by Bank Sumatera Utara Kampung Baru Medan Branch can be explained by the factors of Competitive Advantage and Motivation while the rest are $22.3 \%$ was explained by other factors such as competence, organizational commitment, compensation and others not studied in this study.

Acknowledgement: None

\section{Conflict of Interest: None}

\section{Source of Funding: None}

\section{REFERENCES}

1. Alex Soemadji Nitisemito. (2001). Manajemen Personalia.Jakarta: Ghalia Indonesia

2. Chan, Syafruddin. 2003. Relationship Marketing: Inovasi Pemasaran yang Membuat. Pelanggan Bertekuk Lutut, Cetakan Kedua. Jakarta: Penerbit Gramedia.

3. Deluga, R. J. 1998.Leader-member exchange quality and effectiveness ratings: The role of subordinate-supervisor conscientiousness similarity. Group and Organization Management, 23, 189-216

4. Dessler, Gary, 2007, Manajemen Personalia, Edisi Ketiga, Jakarta: Erlangga.

5. Ferdinand, Augusty. 2006. Structural Equation Modelling Dalam Penelitian. Semarang: FE UNDIP.

6. Gibson, J.L., Ivancevich, J.M., dan Donnely Jr., J.H. 2000. Organisasi dan Manajemen: Perilaku, Struktur dan Proses.Penterjemah: Djoerban Wahid, Jakarta: Erlangga

7. Gordon, Judit R, 2003, A Diagnostic Approach to Organizational Behavior Boston: Allyand Bacon.Penterjemah Hadi, Soetrisno, Jakarta: Erlangga

8. Hadari Nawawi, 2006 Mengefektifkan Organisasi, Yogyakarta Penerbit: Gadjah Mada University Press

9. Handoko, Hani ,2001 Manajemen Personalia\& Sumberdaya Manusia Edisi 2, Penerbit BPFE Yogyakarta

10. Hasibuan, Malayu S. P. 2008. Manajemen sumber daya manusia, Jakarta: PT. Bumi Aksara.

11. Luthans, Fred. 2006, Perilaku Organisasi, Edisi Pertama.Yogyakarta, Penerbit Andi, Penterjemah: Vivin Andika Yuwono dkk.

12. Mangkunegara, Anwar Prabu. 2005. Sumber Daya Manusia perusahaan. Bandung: Remaja Rosdakarya.

13. Mangkunegara, Anwar Prabu. 2009. Evaluasi Kinerja Sumber Daya Manusia. Bandung: Penerbit Refika Aditama Mangkuprawira. Tb Syafri 2004, Manajemen SDM Strategik, Jakarta: PT Ghalia

14. Mathis, Robert. L \& JacksonJohn.H, 2001.Manajemen Sumber Daya Manusia, 
Kiki Farida Ferine. Analysis of the influence of competitive advantages and motivations on the performance of SMEs assisted by Bank Sumatera Utara Kampung Baru Medan Branch.

Jakarta Buku Satu, Edisi Indonesia, PT Salemba Empat

15. Purwanti, Dwi. 2012. "Peranan Seorang Guru". Diakses dari www.infodiknas.com

16. Rivai, Veithzal, 2006. Manajemen Sumber Daya Manusia untuk Perusahaan: dari Teori Ke Praktik. Jakarta: Penerbit PT. Raja Grafindo.

17. Robbins, Stephen P dan Judge. 2008. Perilaku Organisasi, Edisi Duabelas, penterjemahDiana Angelica dkk, Jakarta Penerbit. Salemba Empat:
18. Siagian, Sondang. P. 2006.Sistem Informasi Manajemen. Jakarta: PT. Bumi Aksara.

How to cite this article: Ferine KF. Analysis of the influence of competitive advantages and motivations on the performance of SMEs assisted by Bank Sumatera Utara Kampung Baru Medan Branch. International Journal of Research and Review. 2021; 8(4): 235-244. DOI: https://doi.org/10.52403/ijrr.20210431 